\title{
(POST)COLONIAL DISCOURSE AND THE IRISH SELF IN THE WRITINGS OF J.S. LE FANU
}

\author{
Richard JORGE \\ European University of the Atlantic, Spain \\ richard.jorge@uneatlantico.es
}

DOI: https://doi.org/10.36892/ijlls.v1i3.60

\begin{tabular}{|c|c|}
\hline $\begin{array}{l}\text { Received: } \\
\text { 06/10/2019 }\end{array}$ & $\begin{array}{c}\text { Abstract } \\
\text { It is widely accepted that the relationships of dominance between the Self }\end{array}$ \\
\hline $\begin{array}{l}\text { Accepted: } \\
\text { 15/12/2019 }\end{array}$ & $\begin{array}{l}\text { and the other are concurrent to both the Gothic genre and postcolonial } \\
\text { theory. In Gothic literature, this relationship has traditionally been } \\
\text { expressed through the dichotomy self vs. other, in which the self is the male } \\
\text { protagonist while the latter is "evervthing else in that world" (Dav 19). }\end{array}$ \\
\hline $\begin{array}{l}\text { Keywords: } \\
\text { Postcolonialism, Gothic, } \\
\text { Irish literature, J.S. Le } \\
\text { Fanu, Colonial Discourse, } \\
\text { Short Story }\end{array}$ & $\begin{array}{l}\text { Gothic literature is, thus, an exploration of the formation of identity. In } \\
\text { colonial Gothic, this is brought under the axiom colonizer-colonized, and, } \\
\text { therefore, characters are analyzed as manifestations of a dichotomy which } \\
\text { usually links first the other to the monstrous, who is subsequently presented } \\
\text { as the colonized subject. The Irish case further complicates this simple } \\
\text { binary relation. The running argument of the present paper is that far from } \\
\text { being a dichotomy, the Irish case is better understood as a triangle in } \\
\text { which two of its vertices are fixed-Catholics/Irish and English-while the } \\
\text { third vertex, that of the Anglo-Irish, gradually shifts positions from the } \\
\text { English to the Irish one, following a creolization process in which they are } \\
\text { both victims and victimizers. The characters in the fictions of J.S. Le Fanu } \\
\text { all epitomize this constrained relationship, displaying an array of roles } \\
\text { who do not comfortably fit into either category, showing a pervading } \\
\text { feeling of being ill-at-ease. As this paper shows, a deeper reading reveals } \\
\text { these figures to be just the opposite of what the prototypical colonialist } \\
\text { figure ought to be-weak and feeble, terrorized rather than terrorizer, in } \\
\text { awe of the other instead of subduing it. }\end{array}$ \\
\hline
\end{tabular}

\section{INTRODUCTION}

It is widely accepted that the relationships of dominance between the self and the other are concurrent to both the Gothic genre and postcolonial theory. In Gothic literature this relationship has traditionally been expressed through the dichotomy self vs. other, in which the self is the male protagonist while the latter is "everything else in that world" (Day, 1985, p. 19), Gothic literature being, thus, an exploration of the formation of identity. In colonial Gothic, this is brought under the axiom colonizer-colonized, and, therefore, characters are analyzed as manifestations of a dichotomy which usually links first the other to the monstrous, who is subsequently presented as the colonized subject. However, as was pointed out earlier on, the Irish case further complicates this simple binary relation. The running argument of the present paper is that far from being a dichotomy, the Irish case is better understood as a triangle in 
which two of its vertices are fixed_Catholics/Irish and English_while the third vertex, that of the Anglo-Irish, gradually shifts positions from the English to the Irish one, following a creolization process in which they are both victims and victimizers.

As an example of this, in Terror and Irish Modernism, Hansen (2009) explores how domesticity was used as a metaphor for the Irish-English relationships. After the 1800 Acts of Union, Hansen explains, both British and Irish media explored this metaphor to show how useful or useless the Union might prove. In this dichotomy, the British showed themselves as the sturdy husband, willing to give protection to the feeble, weak female-portrayed Ireland. Traditional postcolonial readings have seen in depictions like this an instance of many an attempt to colonize and subjugate peoples. However, as Hansen reminds us, the difference in the Irish case is that both sides used the same metaphor, even if for different purposes. In Irish Gothic, then, marriages are presented as the failure of domesticity; women are not liberated by the marriage institution but rather entrapped in it, isolated and recluse, thus abrogating the British ideological apparatus. The familial relationships shown in Irish Gothic, then, can be read in terms of political representation. An exploration of Burke's Reflections on the Revolution in France reveals such a reading plausible, "[m]oreover, by imagining the social world via the metaphor of domestic affection, Burke conflates the affective language of the intimate and domestic spheres with the practical and political language of the public sphere" (Hansen, 2009, p. 13).

This use of domesticity, however, reveals more than female representations in Irish Gothic. It must be remembered that the perception of Ireland as feminine was extended to the country itself and not just to its female inhabitants. Therefore, the Irish male was also perceived as having female qualities. This is not new since the Irish_indeed, the Celt_ had always been portrayed, again in what postcolonial theory would define as a feminization of the colonized other, as rather effeminate and child-like, somehow inferior to the Anglo-Saxon race (Innes, 2007). This reading does, nevertheless, have a significant effect on male characters in Irish Gothic fiction. Hansen (2009) stated that:

The Irish male depicted in this fiction experiences the internal incommensurability that follows from this apparently impossible dualism. Like the women of the female Gothic, he finds himself confined in Gothic houses, but if he attempts to escape, he is immediately coded as excessive, violent and irresponsible. Irish masculinity finds itself [...] incapable of wholly embodying either the masculine authority or the feminine passivity demanded by the dualistic and misogynistic Western culture. (p. 12)

It is precisely because of this dualism that the male characters portrayed in the fictions of J.S. Le Fanu resist an easy classification under the dichotomy self vs. other, since in many instances they are both at the same time. The central topic of this paper is that the Anglo-Irish are in possession (or perhaps it would be better to say they are possessed) of this double status as colonizers and colonized, prototypical of creole and settler societies. As will be seen, analyzed in the context of the Protestant cultural nationalism of the 1830s, the texts seem to promote a creolization of Irish society, in a move away from the ties which link the Anglo-Irish Ascendancy class to their English background. The expression Protestant cultural nationalism refers here to the apparition in the early nineteenth century of a sentiment among Irish Tories to 
reclaim their sense of Irishness as opposed to the incipient Catholic nationalism. Based on the principles ascribed by Edmund Burke (1729-97) and having as its main means of expression the literary Dublin University Review, the principles of this movement can be summarized by Samuel Ferguson's 'A Dialogue between the head and the heart of an Irish Protestant,' published in 1833 in the DUM, which contains "the early and cogent expression of the dilemmas of Protestants, disillusioned with British governments and seeking cultural leadership in a country, the religion of whose majority they disliked and suspected" (Murphy, 2003, p. 80).

Characterizations and representations of the self play a crucial role in this process. These stories explore the complex relationship colonized and colonizer subjects have not only with their native lands but also with the metropolis, representing the struggle of the self and the other, and in which sometimes the barrier between one and the other is not clear-cut. These two principles are dominated by two opposing forces, that of submission and of possession, which are also at work in the tense relationships between the colonized and colonizer. Viewed in this way, "the act of writing texts of any kind in post-colonial areas is subject to the political, imaginative, and social control involved in the relationship between colonizer and colonized" (Ashcroft, 1989, p. 29). However, as the analysis will show, the characters at play do not epitomize the figure of the colonizer; rather, they portray in-between figures, colonizers but not quite, in an attempt to "decolonize the mind," and in a move forward to the creation of a shared national consciousness.

Given that the main aim of postcolonial writers is to recover and reclaim lost identities, and to recuperate and reinvigorate and free a dominated culture, it is striking that J. S. Le Fanu chose as the principal subjects for his stories an array of characters which can only be identified with the upper-Protestant classes. A rapid review of Le Fanu's characters will reveal such a cast of protagonists. "Mr Justice Harbottle" has as a main protagonist a gouty, cruel judge who ends up by hanging himself, while "The Familiar" portrays the misadventures of Captain Barton, a former member of the merchant marine and soon to marry into a well-to-do Dublin family. Such representations are striking since Le Fanu could be said to have been representing his own class.

This seems to be in direct opposition with the general tendency in postcolonial writing, in which the need to reclaim history, to tell the many histories of colonized peoples from the point of view of the marginalized other, seems to be the main priority, what Boehmer (2005) terms "historical retrieval", a concept which implies a process "through which historically damaged selves could be remade" (p. 185) and which would include some sort of reclamation of oral memory. Characters like peasants, slaves or fishermen, are noticeably absent, in the vein of much colonialist narratives, or they perform secondary roles, usually remaining in the background (Boehmer, 2005).

Despite the growing importance these characters acquire during the evolution of the genre__ no doubt a reflection of the importance Catholics were gaining in Irish society throughout the nineteenth century_, it is still true that the Irish Gothic short story does not give voice to the subaltern in an overt way as other postcolonial traditions would do. This, however, does not imply that there is no criticism of the colonial question. The method consists in adopting the imperialist perspective to be able to criticize it later on, even if in a somewhat veiled way. It is what could be termed a criticism from within, a denunciation of the colonial 
situation but placing the focus on the figure of the colonizer rather than on the colonized. A clear act of what postcolonial theory terms abrogation. Therefore, in a striking contrast with most postcolonial writing, the self whom the reader encounters in the Irish Gothic short story seems to be that of the colonizer.

This 'seems' already betrays an ambiguity, an ill-at-ease state in the characters, who do not comfortably fit into this category. This paper started by asserting that the dichotomy colonized-colonizer could be reductionist, as recent criticism has shown. Earlier on, it was suggested that some parallelisms could be drawn between the Anglo-Irish Ascendancy and these characters, most notably, their social status. There is also another key factor which links them to this class, that is, that they are not real colonizers. Their social position, inherited from their colonizer forefathers, places them as agents_ and sufferers _ of the colonial quest. Lawyers, landlords, members of ancient landed families, all enforce and benefit from what can be read as colonial rule but there is no "protagonist concerned to define his own identity, enthusiastic about training for imperial service, and convinced of his ability "to shine" (Boehmer, 2005, p. 60). Instead, the reader is presented with an array of characters very much at odds with the role they have inherited.

Even when presented in their prime_ as owners of estate houses and/or as members of the nobility_ the Anglo-Irish Ascendancy is usually enveloped in an aura of decay. Edgeworth's Castle Rackrent, written just right after the momentous loss of the Anglo-Irish Parliament preempts later similar representations. Likewise, John Melmoth's aristocratic family inhabit their now derelict mansion- "As John slowly trod the miry road which had once been the approach, he could discover, by the dim light of an autumnal evening, signs of increasing desolation since he had last visited the spot, - signs that penury had been aggravated and sharpened into downright misery" (Maturin, 2000, p. 11). It is both curious and telling that the ascent of the Irish Gothic short story coincides with the waning of the Ascendancy.

By the 1830s, most of the revolutions which had taken place during the first years following the Acts of Union_ White-boys, Shanavest, Caravats_ were over, including the failed attempt led by Robert Emmet in 1803. Moreover, although the sentiment of Anglophobia and the recital of historical grievance_ along with the metaphor of the failed marriage_ were widespread and helped consolidate the nationalist feeling (Foster, 1989, p. 155), the 1830s saw a new wave of nationalism in politics led by the charismatic Daniel O'Connell, who would manoeuvre to obtain political capital for himself and for Ireland, mostly through peaceful means, a movement which significantly influenced Le Fanu. Similarly, the Tithe Wars, which had plagued the land for over a decade, were over by 1830 and were politically addressed by the Irish Church Temporalities Act (1833) and later by the Tithe Rent Charge (1838). Although sectarianism was high both in Britain and Ireland in the first three decades of the nineteenth century, by the 1830 s the Ascendancy rule over Ireland was effectively over, partly due to Westminster's efforts to "develop a neutral machine of control" (Murphy, 2003, p. 22). Dublin, for instance, had become an amalgam of lawyers and doctors belonging to the mostly Protestant_ upper-middle classes. The education issue had been also partially addressed through the creation of a National Education System, which did much to enlighten the poor classes. Although inequality was still evident, there was certain prosperity to be enjoyed by some Catholics and Presbyterians who now belonged to the middle-classes and the bourgeoisie, an ascent mainly prompted by the Napoleonic Wars, a fact which might have preoccupied the 
Ascendancy class, since it constituted a threat to their privileges and status. Despite this, it would be wrong to think that the divide between the Protestant Ascendancy and the native Catholic population was over. As Foster asserts, "[ $\mathrm{t}] \mathrm{o}$ be a Protestant or a Catholic in the eighteenth-century indicated more than a mere religious allegiance: it represented opposing political cultures, and conflicting views of history" (Foster, 1989, p. 136). This divide was to be maintained by a crucial episode in Irish history_ an GortaMór or the Great Famine, which was to have lasting effects reflected in the literature written in the period by Le Fanu. There can be no doubt that some of the guilt which plagues the writings of these two authors stems from the role the Protestant Ascendancy played during those years. It is, however, this last term, 'Ascendancy', which is problematic.

The fact remains that Irish society was, at that time, a more complex construct than more reductionist views would have it, and although traditional postcolonial criticism has tended to see a clear-cut divide Colonizer/Protestant Ascendancy vs. Colonized/Catholics, the picture is more elaborate than that. Recent scholarship promotes an interpretation that escapes this binary model, arguing that_especially in the Irish case_ it is reductive. Contrary to those critics who dispute Ireland's claim to a postcolonial interpretation, Wright (2007) asserts that "we need to question more thoroughly the utility of binary formulations in order to grasp more fully the complexity of an imperial history that reaches across, and builds upon, different historical moments, geopolitical situations, imperial ideologies, and discourses of resistance" (pp. 5-6). Hansen (2009) has expressed himself in similar terms, arguing that:

This critical approach often imagines Anglo-Ireland as the lone name for colonial false consciousness, rather than as one hybridized component of a more complicated cultural and socio-political matrix that includes Catholics of the bourgeois, proletarian, and agrarian variety, a divided, declining AngloProtestant ascendancy, and an oft-overlooked Anglo-Protestant middle class. (p. 9)

On a first reading, the characters seem to be perpetuating the figure of the colonizer and of colonial status and, therefore, the subaltern other is filtered through the colonial gaze, thus maintaining the mainstreams of colonial discourse, or "the systems of cognition [...] which Europe used to found and guarantee its colonial authority" (Boehmer, 2005, p. 48) by which the other is shown as "less human, less civilized, as child or savage, wild man, animal, or headless mass" (Boehmer, 2005, p. 76). However, the question which criticism should consider is whether this superficial reading holds.

A deeper reading will show this figure to be just the opposite of what the prototypical colonialist figure ought to be_ weak and feeble, terrorized rather than terrorizer, in awe of the other instead of subduing it. As Boehmer (2005) reminds us, masculinity and its exertion of power were pivotal in the colonial quest; thus, by making the male figure the centre of its criticism, the Irish Gothic short story performs a double function_ it exposes the unsuitability of the Anglo-Irish Ascendancy as a ruling class for their inaction and connivance with the colonizers, and it criticizes the application of the colonial system in Ireland. Thus, the Irish Gothic short story questions one of the tenets of colonial discourse, which is appropriated and subverted, and exposed in a completely different light. Le Fanu's appropriation of the colonialist voice is, in fact, a trend which had been started earlier on, by J.C. Mangan. Far from being colonialist literature, he provides an analysis and a criticism of the Anglo-Irish ruling 
class by showing them as helpless and self-centred characters, embedded in a paralysis product of their double status as colonized and colonizer subjects, thus questioning their identity as a class.

\section{DISCUSION}

Guilt is the domain of Joseph Sheridan Le Fanu, a Dublin-born Protestant whose ancestor, Charles de Cresserons, "had fought for William of Orange at the Boyne" (McCormack, 1991, p. 1). Flannery highlights how Irish Gothic has been the instrument through which anxiety, paranoia and subversion have been dealt with in Ireland (Flannery, 2006, p. 92), while Gibbons points at how "[t]he ghosts of the Catholic/Gaelic order indeed roam the landscape, but that is because they have been released from their vaults by recurrent Protestant terror" (Gibbons, 2004, p. 58). In a similar vein, Hansen (2009) sees Anglo-Irish Gothic fiction as obsessed with "guilt-ridden ruminations on landlordism, its troubled representations of class, sectarian and [...] racial difference, and its compulsive dread of the claustral" (p. 28). It comes as no surprise then that many a critic has appreciated these Gothic tropes in Le Fanu's writings. In his introduction to his challenging study of Le Fanu's narrative techniques, Sage argues that "we now have no difficulty in seeing [Le Fanu's] Gothic, along with that of Charles Maturin and Bram Stoker, and even Elizabeth Bowen, as articulating the attenuated, hyphenated existence of a dying Protestant Ascendancy caste" (2004, p. 1), while in his introduction to Le Fanu's last collection of stories ( In a Glass Darkly), Tracy (1993) assures that the supernatural story often reflects the hidden anxieties of its writer; reflecting on the title Le Fanu chose for his collection, he pinpoints that "[ $t$ ]he glass of his title is not a window-pane through which we glimpse dim intimations of a spiritual world, or of divine truth. It is a mirror in which we glimpse our own darker nature" (P. xv). Le Fanu's relationship with politics, his own class and Irish nationalism was always an ambiguous, if not troublesome one. Despite being a convinced Tory, he always showed admiration for Jacobinism, and much of his writings are in the vein of a criticism of the Anglo-Irish elite, "instead of a monopoly of Jacobite heroics his fiction now introduced Williamite guilt" (McCormack, 1991, p. 82). In a similar way, Le Fanu was attracted by Young Ireland and supported the Repeal movement_ however blandly_ but despised O'Connell and his rhetoric. So strong was this detestation that it ultimately "penetrated the 'code' of his historical fiction to make the identification of his own caste and the earlier Jacobites intolerable" (McCormack, 1991, p. 86). His writings are, however, denunciatory of the colonial system which dominated Ireland and of its effects. Le Fanu shows all the pillars of Anglo-Ireland to be haunted by guilt, which can be traced back to the historical events which empowered his class. Those characters representing the Ascendancy_ the military, the judiciary, the medical, and the land owning class_are almost invariably linked with explicit criminal offences if not the monstrous other directly (McCormack, 1991).

This reading of Le Fanu's writings is not an argument which the present thesis wishes to disprove; much the opposite, indeed. However, it seems a shade of interpretation has been left out. Truth be told, Le Fanu's characters are filled with anxiety and hidden guilt, traits which manifest themselves in the other which_quite literally_ follows and haunts them. It would not be too far-fetched an assertion to say that all the characters in Le Fanu are haunted, however differently. While some of his later characters are haunted by guilt and remorse, there are also others who are haunted by their fate. It is no coincidence that these can be classified into what 
MacComack (1991) has termed Le Fanu's Catholic and Protestant stories. This distinction can be better appreciated in his first collection of short stories (The Purcell Papers) which also coincides with Le Fanu's temporary flirtation with politics (McCormack, 1991). While Le Fanu'soeuvre has been thoroughly analyzed, much of the critical corpus which has been dedicated to him has focused on Uncle Silas or_ when analyzing his shorter fiction_ In a Glass Darkly. Hardly can this be considered a mistake, since, from the perspective of an Anglo-Irish canon, those two works are most reminiscent of the Anglo-Irish Ascendancy in their portrayal of a guilt-ridden class. However, they are _ paradoxically enough_also the least Irish of Le Fanu's works, so much so that, as Sharon May Gallagher reminds us, he_along with Maturin and Stoker_ was not included in the canon of Irish national literature as described by Yeats (Gallagher, 2004, pp. 13-17). However, literary scholarship has overlooked the importance The Purcell Papers has in relation to colonial discourse, since it constitutes Le Fanu's most overt defence of the precepts of cultural nationalism as defined by Burke.

The Purcell Papers establishes a touchstone in Le Fanu's literary career as a short story writer and in his whole oeuvre. In fact, there are many resemblances between The Purcell Papers and In a Glass Darkly. Both collections show an overall tone of unity granted by several factors, like their resourcing to the usage of the embedded narrative: the narrative voice which introduces the stories is authorized both by its moral superiority and by its distance with the reader, the narrative being presented as a recollection from the past. To complicate things further, this is a different voice to that of the collector and presenter of the stories, who plays the role of transmitter, a linking device between past and present; there is yet a third narrative figure present, since in many of the stories, the narrator is a different voice to that of Purcell/Hesselius. The stories represent a questioning of authority since their authorship and veracity cannot be attested nor refuted. In fact, the narrator of In a Glass Darkly acknowledges the possibility of misinterpretation by admitting to editorial intrusion, "[the stories] are written, some in English, some in French, but the greater part in German. I am a faithful, though I am conscious, by no means a graceful translator, and although here and there I omit some passages, and shorten others and disguise names, I have interpolated nothing" (p. 6). Despite claims to a faithful reproduction and translation, authority is questioned here, as there is no guarantee of the importance of what has been left out and the unveiled reasons to do so.

Both the tale-within-a-tale and the manuscript devices create the ambivalent sensation of being at the same time facing the familiar and the strange. The use of shadowy narrators causes in the reader the "sense that the strange story is mediated through someone who belongs to the familiar world" (MacAndrew, 1979, p. 112). All this disguising of names, this obscure authorship, questions any plausible claims to authority in the same way it questions the veracity of tales and stories. This device puts into question the veracity of the mainstream narrative of colonial discourse, which reduced the Irish to a sub-race, while at the same time remarking upon the volubility and complexity of identity, a consistency with the characters that the stories display. Overall, both narrative techniques and characterisation build towards a questioning of identity, both national and colonial.

Le Fanu's characters are complex to analyse owing to the fact that Le Fanu was the more prolific writer of short stories of the two. However, a classification and analysis can be established comparing those characters who appear in The Purcell Papers and those appearing in In a Glass Darkly, both of which lie at either ends of Le Fanu's writing career. Sage (2004) argues that Le Fanu's first "rhetorical opportunity comes in the context of a political pressure: 
that of Protestant cultural nationalism in the Dublin of the late 1830s" (p. 11). This implies reconciliation between Catholics and Protestants, and a further move towards the creation of a common, shared identity. Indeed, much of his work does seem to position itself in that direction. Most of The Purcell Papers stories are wrought around Irish characters, of conspicuously Anglicized Gaelic names, like Donovan or Sullivan. There is also an overt attempt to recuperate the past and an overt idealization of the Gaelic/Catholic, as will be seen in the subsequent section. Given the span of Le Fanu's career as a short story writer and, in an attempt to show how Le Fanu questions colonial discourse, representations of the self will be analyzed in two different stories at either ends of his writing career, A Chapter in the History of a Tyrone Family (1839) and The Familiar (1872), taken from The Purcell Papers and In a Glass Darkly, respectively.

A Chapter in the History of a Tyrone Family was first published in the Dublin University Magazine in 1839, and adheres to the structure already mentioned_it is Purcell who introduces the narrative in a eulogist style, claiming to be merely a transmitter of a truthful narration, "I have endeavoured to give as nearly as possible the ipsissimaverba of the valued friend from whom I received it" (Le Fanu, 2007, p. 193), only to subsequently allow the female narrator to have her say. Paradoxically, the narration is then rounded up, for it is Purcell who brings it to an end, again conspicuously claiming verisimilitude, "we shall be found not to have taken [...] any liberties with the facts, but in our statement of all the incidents to have rigorously and faithfully adhered to the truth" (Le Fanu, 2007, p. 232). Additionally, the story reworks the locked-room motif which had appeared previously in Passage in the Secret History of an Irish Countess. In both stories Le Fanu uses a female narrator through whom the reader sees the story and who ends up locked up in a room, both stories serving as a portrayal of the dysfunctional family.

The narrative technique Le Fanu employs in this story is quite peculiar, indeed, for it is made up of two different stories altogether. The first story is a recount of an uncanny incident which took place in the distant past, when the narrator was a child. She informs the reader that she had a sister, who got married to Mr. Carew, "a gentleman of property and consideration in the north of England" (Le Fanu, 2007, p. 194). Her sister's wedding produces in her "sorrowful feelings" which contrast strongly with the "thronging carriages, the noisy menials, the loud laughter, the merry faces, and the gay dresses" ((Le Fanu, 2007, p. 194). After the wedding, the married couple leave for the north of England but return a year later "as the physician who had been consulted [...] strongly advised a removal to her native air" (Le Fanu, 2007, p. 195). This arrival, however, never takes place for the sister dies right after midnight, her death having been announced previously in an uncanny vision as in:

I now heard the shrill screaming of the rusty iron, as the avenue gate revolved on its hinges; again came the sound of wheels in rapid motion.

'It is they,' said I, starting up; 'the carriage is in the avenue.'

We all stood for stood for a few moments breathlessly listening. On thundered the vehicle with the speed of a whirlwind; crack went the whip, and clatter went the wheels, as it rattled over the uneven pavement of the court. A general and furious barking from all the dogs about the house, hailed its arrival. (Le Fanu, 2007, p. 196)

Of course, when they all go to the courtyard to welcome the couple, they find it empty, and they stare at this void "as if suddenly awakened from a dream; the dogs walked 
suspiciously, growling and snuffing about the court" (Le Fanu, 2007, p. 196). The previous paragraph is suggestive of a vision_ the spirit of her sister is trying to return home, a fact that Le Fanu attempts to underscore by placing 'objective' witnesses_ the dogs (Sage, 2004).

This introductory story serves two purposes. First, it introduces the supernatural element_a premonitory vision which the narrator perceives, an omen of death and a pattern which will reappear in the second story. Second, it paves the way for a recurrent motif in Le Fanu's fiction_the dysfunctional family. Right at the beginning of her narration she states that her sister's tenderness "alone had hitherto more than supplied all that I wanted in my mother's attention", while two paragraphs later she expostulates that her father "never seemed to love or take an interest in me. [...] My having come into the world at all as his child he regarded as a kind of fraudulent intrusion" (Le Fanu, 2007, 194). All this causes Fanny_ the narrator-to be "so wretchedly low-spirited and nervous, that I could scarcely be said to live" (Le Fanu, 2007, 198), and she becomes, naturally enough, an isolated being, indecisive and afraid. This has, of course, much to do with Le Fanu's loophole technique, as such a character is more prone to hallucinations than a more self-confident one, making a logical explanation more plausible. This, however, does not diminish the dysfunction of the Anglo-Irish family which the Dublin writer is about to display.

The focus of this section is, notwithstanding, the male self as a representation of the Anglo-Irish, and this makes his appearance in the second story in the figure of Lord Glenfallen. In this story, Fanny is introduced to high society, for which a change of scenery is necessary, and thus she leaves Ashton House for Dublin, which produces a change in the narrator's mood, "[t]he tumult and novelty of the scenes in which I was involved did not fail considerably to amuse me, and my mind gradually recovered its tone, which was naturally cheerful" (Le Fanu, 2007, p. 199). Fanny starts to attend social events as corresponds to a member of her class, no doubt with the aim_ carefully schemed by her mother_ to find a prospective partner. This is later clarified in the story, when Fanny's mother, willing to retire for the day, informs Fanny that Lord Glenfallen is in love with her. The extract, though of some length, is worth quoting as follows:

'Well, well, my dear,' said my mother, impatiently; 'do you know who Lord Glenfallen is?'

'I do, madam,' said I rather timidly, for I dreaded an altercation with my mother.

'Well, dear, and what frightens you?' continued she. 'Are you afraid of a title? What has he done to alarm you? He is neither old nor ugly.'

I was silent, though I might have said, 'He is neither young nor handsome.'

'My dear Fanny,' continued my mother, 'in sober seriousness you have been most fortunate in engaging the affections of a nobleman such as Lord Glenfallen, young and wealthy, with first-rate-yes, acknowledged FIRST-RATE abilities, and of a family whose influence is not exceeded by that of any in Ireland. Of course you see the offer in the same light that I do-indeed I think you MUST.' (Le Fanu, 2007, 201).

This extract is very telling for several reasons; first, it reminds the reader that the whole idea of matrimony is that of status and wealth, being love - or even physical attraction - out of the question. Most importantly for the present section, the extract introduces Glenfallen through the eyes of two different female characters. For Fanny_who has already been linked to the psychological and the uncanny_, is neither handsome nor ugly, neither young nor old; that is, 
Glenfallen is a rather grey, dull character, possessing no distinctive characteristics of his own. For her mother, however, he displays "first-rate abilities", that is, wealth and connections. Nevertheless, these can barely be classified as such, since richness and family influence can hardly be described as "abilities". Be it as it may, they are external characteristics, having little to do with Glenfallen's personality. In a surprising reversal of roles, then, Glenfallen is feminized; he becomes the object of desire of the female gaze because he symbolizes a link to property and status, that is, wealth; a link usually associated with female characters. Le Fanu is already portraying a characteristic which Hansen (2009) considers intrinsic to male characters in Irish Gothic fiction_ their female traits. This adoption of female characteristic such as passivity can be linked to the 1800 Act of Union and the loss of power it implied. Although the Act of Union meant a lasting Protestant influence in Ireland, it also implied a swift in decisionmaking from Dublin to Westminster. True, the Anglo-Irish retained their power but they were unable to exert it. As Moynahan (1995) asserts:

After the Union, the Dublin parliamentarians, for so long and so brightly a force in Irish politics, culture, and society, discover they have a choice between dispersing themselves to a life of decent though uneasy obscurity on their rural estates and trying to launch new political careers in a Westminster parliament whose leaders regard most of them as provincials and natural back benchers. [...] This ends the Ascendancy political monopoly and guarantees that the small and shrinking Anglo-Irish electorate will no longer enjoy the assurance of being represented by persons of their own class and class interests. (p. 11)

In the same way, Lord Glenfallen possesses power but_as the story will prove _ he is unable to exercise it, even within his own domains.

However, the extract also speaks of perceptions and misperceptions, of the possibility of multiple personalities in one, and of hidden traits. This is reinforced later on, when Fanny describes her feelings towards Glenfallen, finding him pleasing, agreeable and well-informed, a man "whom I was always glad to meet in society", and who "had served in the navy in early life" (Le Fanu, 2007, p. 202). Maybe rather unknowingly_ for she possesses traits of the ingénue _, Fanny is already underscoring a difference between private and public selves, which are presented as opposites. It follows, then, that there is a side to Glenfallen which the reader or Fanny, for that matter_ does not know, and which (as opposed to his pleasing public manners) might hide dark, uncanny aspects, as the reader will eventually find out. This idea is, of course, heightened by the reference to the navy and the concurrence of two ways of behaving which apparently is presented as a positive fact, "the polish which his manners received in his after intercourse with courts and cities had not served to obliterate that frankness of manner which belongs proverbially to the sailor" (Le Fanu, 2007, p. 202).

There is a subsequent change of scenery following Fanny's and Glenfallen's marriage; if the narrator had left the Anglicised Ashton Hall for the Anglo-Irish metropolis, this time the journey will take her to Gaelic heartland, Cahergillagh, "one of the Glenfallen estates, lying, however, in a southern county, so that, owing to the difficulty of the roads at the time, a tedious journey of three days intervened" (Le Fanu, 2007, 204). Cahergillagh and its castle are, of course, where the uncanny is going to take place, and to heighten which the first story was introduced by Le Fanu. Glenfallen's comments on it as an enchanted castle, and the narrator's pastoral description as she approaches it, encourage this vision, "A lake of considerable extent stretching away towards the west, and reflecting from its broad, smooth waters, the rich glow of 
the setting sun, was overhung by steep hills, covered by a rich mantle of velvet sward [...]" (Le Fanu, 2007, p. 205). But what is most interesting about this encounter is, of course, Glenfallen's reaction to it, which contrasts powerfully with Fanny's positive and romantic vision. For him, the mansion is a symbol of the negative, so much so that he feels obliged to excuse himself,

'You must not, my love,' said Lord Glenfallen, 'imagine this place worse than it is. I have no taste for antiquity [...]. Indeed I do not recollect that I was even so romantic as to overcome my aversion to rats and rheumatism, those faithful attendants upon your noble relics of feudalism. (Le Fanu, 2007, p. 205)

Glenfallen's comments on feudalism, along with the description of the castle, undoubtedly of military use, ineludibly link him to Ireland's history of colonialism, that part of his past and his private self which disgusts him and which he attempts to reject, however unsuccessfully, for he considers himself "modern and unmysterious" (Le Fanu, 2007, p. 205). Glenfallen, like the Anglo-Irish caste, is a man haunted by his feudal past, a past he tries to escape but which comes back to take its rightful place among the living. The apparition of the uncanny and its manifestation to Fanny will disclose Glenfallen's private self, which will, eventually, take over from his public one. On the very first day, Fanny has a premonitory vision and foreshadowing. On entering her room, she seemingly sees a black tapestry fall; this, however, she discovers to be mere fancy_there is no tapestry whatsoever as all the rooms are wainscoted but the episode unveils an uncanny story (revealed, of course, by the servant), "Whenever something something BAD is going to happen to the Glenfallen family, some one [sic] that belongs to them sees a black handkerchief or curtain just waved or falling before their faces" (Le Fanu, 2007, pp. 208-9). This episode anticipates Glenfallen's subsequent change of humour; he becomes silent and moody, uttering the following, "'Twere madness-madness-madness," repeating the words bitterly- "sure and speedy ruin"” (Le Fanu, 2007, p. 209). From now on, the action takes a definite Gothic turn, as Glenfallen makes Fanny promise that she will not go to the back part of the castle nor to the adjacent garden, which is surrounded by high walls.

As time passes by and the married couple prolong their stay in Cahergillagh, the third uncanny event takes place. One day Fanny enters her room but finds in it an old blind lady sitting in a chair who calls herself 'Lady Glenfallen'. Fanny naturally reprimands the old lady, assuring her that she_Fanny_ is Lady Glenfallen, to which the former reacts in a violent outburst, "“[i]t's a lie, you trull!' cried she, in an accent which made me start, and at the same time, springing forward, she seized me in her grasp, and shook me violently, repeating, 'It's a lie-it's a lie!"” (Le Fanu, 2007, p. 212). Glenfallen, naturally, tries to convince Fanny that the old woman is mad. Although the old lady is enveloped in uncanny characteristics, and Glenfallen himself calls her "demon", the relevant fact for the present section is that from this encounter onwards, he will become darker, his private self overcoming the public one, "[L]ordGlenfallen's temper and spirits underwent a complete and most painful change; he became silent and abstracted, his manner to me was abrupt and often harsh, some grievous anxiety seemed ever present to his mind" (Le Fanu, 2007, p. 213). It is clear from this extract that Glenfallen is haunted by his past, which finds its way into the present and ends up catching up with him. By returning to Cahergillagh, Glenfallen has entered a downward spiral - the more he tries to hide his past, the more influence this past has in his present.

The story reaches its climax when the blind Dutchwoman attempts to murder Fanny, after a series of uncanny omens. She is subsequently tried for attempted murderer but, before dying, 
she reveals what seems to be the truth_ "'Hardress, Earl of Glenfallen, I accuse you here in this court of justice of two crimes, _ first, that you married a second wife, while the first was living; and again, that you prompted me to the murder, for attempting which I am to die" (Le Fanu, 2007, pp. 226-7). Further from relieving Glenfallen, the death of the Dutchwoman prompts his final plunge into insanity,

For some time after this event, Lord Glenfallen appeared, if possible, to suffer more than he had done before, and altogether his language, which often amounted to half confessions of the guilt imputed to him, [...] formed a mass of evidence so convincing that I wrote to my father, detailing the grounds of my fears, and imploring him to come to Cahergillagh without delay. (p. 227)

Before Fanny departs, however, Glenfallen's journey into the Gothic underworld terminates in the worst way possible_ he loses his mind and ends up, presumably, committing suicide by effecting the same action with which the blind Dutchwoman had threatened him, "The head hung back, as it seemed, almost severed from the body by a frightful gash, which yawned across the throat. The instrument which had inflicted it was found under his body" (Le Fanu, 2007, p. 232). Le Fanu's attempt at psychological terror_and his loophole effect_ is clear in this ending; just before committing this final act of lunacy, Glenfallen had made out that he was in conversation with Flora Van Kemp (the blind Dutchwoman), who had attempted to kill him in that very same room the previous night. Whether ghost or bad conscience, Glenfallen's past finally catches up with him, and he dies because_ as Fanny words it_ "all was gone_ the dreadful consummation was accomplished_the fearful retribution had fallen upon the guilty man_the mind was destroyed_ the power to repent was gone." (Le Fanu, 2007, p. 230)

Glenfallen epitomizes much of the criticism which can be held against the Anglo-Irish. His unquestionable belonging to the Ascendancy (Earl of Glenfallen), his possessing a castle in the Irish heartland_thus reminding the reader of the colonial heritage_, his inability to take affective action, and his having served time in the navy, all place him as a prime representative of that class. It is this last fact_his belonging to the navy_ which makes him a perfect illustration of the criticism on colonial discourse deployed by Le Fanu. Although not stated, it becomes clear by the end of the narrative that Glenfallen must have served in the merchant marine, one of the tenets of the colonial enterprise_ his having first married a Dutchwoman points in that direction. Ultimately, it is this connection which brings about his downfall. The story, however, attacks a further pillar of colonial discourse.

\section{CONCLUSION}

Often, colonialism was enacted by applying the colonizer's institutions to the colonized, and showing them as better, more cultured and sophisticated. One of the pillars of Victorian society_ and of the British Empire_was family. Nevertheless, Le Fanu presents that tenet as corrupted. Glenfallen is guilty of bigamy, a crime which comes back to haunt him, and which affects not only himself but also his previous wife and his present one, eventually destroying his present and thus portraying the family institution as an unreliable element in a colonized society, taking Hansen's wrong-marriage allegory a step further_there is no domestic peace but rather the opposite: the enemy is within. The colonial element, placed in the past, finds its way into the present, disrupting and ultimately destroying any attempt at familial tranquility, so that "Colonialism not only intervenes in national history, but also the genealogical lines of 
relationship and inheritance which [...] underpin that history" (Wright, 2007, p. 160). Not only is Le Fanu criticising the colonial system, but he is also voicing one of the biggest fears of the Anglo-Irish class, the return of the past. It is important to remember that the Anglo-Irish had voted themselves out of parliamentary existence out of fear of a Catholic return, which in itself stemmed from a deep sense of Williamite guilt. As Gibbons poses it, "In this version of Gothic, the sins of the past become part of the underside of modernity itself as it weighs upon the minds of the living." (Gibbons, 2004, p. 24)

Ultimately, Glenfallen summarizes the denunciatory stance of postcolonial Gothic; the product of the British colonial system in Ireland, he becomes at the same time victim and victimizer. In this story, Le Fanu plays with the figure of the monster - all along its development, monstrosity points at the blind Dutch woman, but it is ultimately Glenfallen who is proven to be the real monster. He is claimed, however faintly, to mistreat his previous wife (Le Fanu, The Purcell Papers, 2007, p. 218), and while he does not treat Fanny in the same way, he ultimately disgraces her by conniving her into a marriage that is outside any legal_or ethical, by Victorian standards_ boundaries. In a rather premonitory way, Glenfallen allegorizes the doom of the Anglo-Irish caste_ haunted by their guilty past, they will bring about their own downfall.

\section{REFERENCES}

Ashcroft, B. (1989). The Empire Writes Back. New York: Rutledge.

Boehmer, E. (2005). Colonial and Postcolonial Literature. Oxford: Oxford University Press.

Day, W. P. (1985). In the Circles of Fear and Desire. Chicago: University of Chicago Press.

Flannery, E. (2006). Versions of Ireland: Empire, Modernity and Resistance in Irish Culture. Newcastle: Cambridge Scholars Press.

Foster, R.F. (1989). The Oxford History of Ireland. Oxford: Oxford University Press.

Gallagher, S. M. (2004). Three Nineteenth-Century Irish Novelists, their Gothic Myth and National Literature: Charles Robert Maturing, Joseph Sheridan Le Fanu and Bram Stoker. Indiana: Indiana University of Pennsylvania.

Gibbons, L. (2004). Gaelic Gothic. Race, Colonization, and Irish Culture. Galway: Arlen House.

Hansen, J. (2009). Terror and Irish Modernism: The Gothic Tradition from Burke to Beckett. Albany: State University of New York Press.

Innes, C. L. (2007). The Cambridge Introduction to Postcolonial Literatures in English. Cambridge: Cambridge University Press.

Le Fanu, J. S. (1993). In a Glass Darkly. Oxford: Oxford University Press.

Le Fanu, J. S. (2007). The Purcell Papers. Gloucester: Dodo Press.

MacAndrew, E. (1979). The Gothic Tradition in Fiction. New York: Columbia University Press.

Maturin, R. (2000). Melmoth the Wanderer. London: Penguin Books. Print.

McCormack, W.J. (1991). Sheridan Le Fanu and Victorian Ireland. Dublin: The Lilliput Press.

Murphy, J. (2003). Ireland: A Social, Cultural and Literary History, 1791-1891. Dublin: Four Courts Press ltd.. 
Sage, V. (2000). "Introduction.” Le Fanu, Joseph Sheridan. Uncle Silas. London: Penguin Books. ix-xxxi.

Sage, V. (2004). Le Fanu's Gothic: the Rhetoric of Darkness. London: Palgrave Macmillan.

Tracy, R. (1993). "Introduction.” Fanu, Joseph Sheridan Le. In a Glass Darkly. Oxford: Oxford University Press. i-xxxiii.

Wright, J. M. (2007). Ireland, India and Nationalism in Nineteenth-Centruy Literature. Cambridge: Cambridge University Press. 